\title{
17. How policymakers imperil coming generations' future and what to do about it
}

\section{Ridhima Pandey}

Ridhima Pandey, a 12-year-old girl, hails from Haridwar town, in the Himalayan State of Uttarakhand in India; she is a student in lower secondary education. Her father, Dinesh Pandey is an environmental activist and her mother works in Uttarakhand Forest Department. From a very young age, Ridhima has been visiting forests and learning about nature and the environment from her parents. Her first encounter with an extreme weather event was the 2013 Uttarakhand floods that resulted in much devastation and loss of lives as well as damage to the Himalayan ecosystem. She witnessed the heart-breaking accounts of loss on the television and read about them in the newspapers. That was when her parents told her that it was all due to climate change. Her parents and teachers also told her lot of things about climate change and guided her on conservation of nature. This disaster affected her deeply and she asked her father, "You work to protect environment and wildlife than why don't you approach the government to save the climate?" Thus, her father decided to file a Public Interest Litigation in her name.

India is one of the countries most vulnerable to the adverse impacts of climate change and it has already experienced several impacts in the form of flash floods, receding glaciers, rising sea levels and other calamities. India is ranked third in the world among the largest emitters of $\mathrm{CO}_{2}$ emissions. Therefore, India has a particularly important role to play in addressing these issues. However, there is no law in existence to deal with climate change issues in India. There are several laws in existence with respect to environmental pollution and to regulation of forest diversion, but they are not framed in a manner to regulate and mitigate the impacts of climate change. Despite signing and ratifying the Paris Agreement, the Government of India has not yet passed any national legislation that the country would need to follow in order to reduce its carbon emissions as well as ensure minimal adverse impacts of climate change on the ground. 
Ridhima approached the National Green Tribunal (NGT) in 2017, raising serious concerns regarding the actions and inaction of the government on the issues of climate change. She is directly affected by the adverse impacts of climate change and rising global temperatures. Children of today and the future will disproportionately suffer from the dangers and catastrophic impacts of climate change. Ridhima pointed to the failure of the Government of India to address the adverse impacts of climate change under the existing framework of environmental law.

\section{VOLUNTARY COMMITMENTS MADE BY INDIA UNDER THE PARIS AGREEMENT}

India has ratified the UN Framework Convention on Climate Change (UNFCCC), which was adopted in 1992 at the UN Conference on Environment and Development in Rio de Janeiro. Under the regime of the UNFCCC, the parties have to submit their Intended Nationally Determined Contributions, which are essentially communications on behalf of the state parties as to how they plan to contribute to the enforcement of the goals of the Paris Agreement, by taking domestic actions in the context of their national priorities, circumstances and capabilities. In December 2015, the Paris Agreement was adopted under the aegis of the UNFCCC, the nations around the world agreeing to "holding the increase in the global average temperature to well below $2^{\circ} \mathrm{C}$ above pre-industrial levels and pursuing efforts to limit the temperature increase to $1.5^{\circ} \mathrm{C}$ above pre-industrial levels". The Paris Agreement was ratified by India in October 2016, whereby India committed to follow a "low-carbon path to progress". However, Ridhima highlighted that this commitment is not reflected in the domestic actions of the government, which has approved several carbon-intensive projects since the Paris Agreement, in complete contravention to the government's own targets and commitments under the said Agreement. In fact, several coal mining projects and coal-fired thermal power plant projects have been considered and recommended for environmental clearance and forest clearance under the provisions of the Environment (Protection) Act, 1986, and Forest (Conservation) Act, 1980, without there being any discussion or any impact assessment on climate-related issues. Evidence was provided to the NGT that the government had failed to take effective measures to address the adverse impacts of climate change, in violation of the existing framework of environmental legislations in the country. 


\section{INADEQUATE PLAN FOR TACKLING CLIMATE CHANGE}

Ridhima's petition before the NGT also highlighted the government's inaction on specific issues of climate change. One of these issues is that the Government's National Action Plan on Climate Change (NAPCC) is not target oriented. This Plan, published in 2008, is merely a list of proposed activities; it doesn't set any time-bound goals with regard to emissions reduction. In fact, it is not even based on an investigation of what are the major sources of emissions in India.

It was also highlighted that the Prime Minister's Council met thrice, in 2009, 2010 and 2011. The Council was reconstituted in 2014, and only one meeting has taken place since then (in January 2015). Hence the NAPCC has not been updated since it was first published in 2008 , despite numerous critical developments in matters of climate change in the international as well as domestic arena, including the release of two reports by the Intergovernmental Panel on Climate Change (IPCC) and the adoption, ratification and entry into force of the Paris Agreement.

\section{DEPLETING CARBON SINKS}

The Petition also highlighted that while India was giving several statements before the world community that the country is well on the path to achieving its targets under the Paris Agreement, in the last one year, the government allowed about 10000 ha of forests to be diverted. Deforestation is the second-largest source of anthropogenic carbon emissions after fossil fuels.

Forestland captures carbon that would otherwise be released into the atmosphere. Thus, when trees are cut down or destroyed, more carbon is emitted into the atmosphere. It was submitted before the NGT by Ridhima that even after having all the data available and threats made visible, no concrete step has been taken by the government that could reduce India's contribution to climate change, especially with regard to the increasing trend in forest diversion and consequent loss of carbon sinks.

\section{RELIEF SOUGHT FROM THE NATIONAL GREEN TRIBUNAL}

Thus, the Petition sought specific directions from the NGT to the government for including mandatory Environmental Impact Assessments (EIAs) of the projects, which require environment clearance under the environmental law regime (EIA Notification, 2006) and also when diverting forest for non-forest 
use under the Forest (Conservation) Act, 1980. The Petition also sought for a realization of an inventory of each and every substantial source of greenhouse gas (GHG) emissions in India. Without such inventories it is not possible to achieve any agreed target. Most importantly, the Petition sought for a time-bound national climate recovery plan within the existing legal framework that includes successive $\mathrm{CO}_{2}$ reduction targets and mitigation actions.

\section{PROCEEDINGS BEFORE THE NATIONAL GREEN TRIBUNAL}

The government, in response to the Petition, asked for the dismissal of the case on frivolous grounds. Its main argument was that the issue of climate change is global in nature and is a policy issue with which the NGT ought not to interfere. The government also stressed that the NAPCC was sufficient to deal with the issue of climate change and there was no need for any further steps to be taken in this regard.

In reality, most of the steps that the government has claimed to have taken are only on paper and in the form of policy frameworks that cannot be enforced or implemented. The government has even diverted money away from the National Clean Energy fund for other purposes. It has granted permission for new thermal power plants in contradiction to statements made by the Ministry of Power. There is no programme in place aiming at sufficiently reducing the use of fossil fuels to achieve the required target of GHG emissions reduction. Burning fossil fuels already causes increased asthma, cancer, cardiovascular disease, heat-related morbidity and mortality, food-borne diseases, and neurological diseases and disorders.

In January 2019, the NGT closed Ridhima's Petition by observing that there is no reason to presume that the Paris Agreement and other international protocols are not reflected in the policies of the Government of India, or are not taken into consideration in granting environment clearances; therefore, there was no need for the NGT to pass any further directions on this issue. What is slightly disappointing is that despite presenting several arguments as well as evidence on the lack of a EIAs while appraising projects, the NGT closed the case on a clearly erroneous presumption. Ridhima has filed an appeal before the Supreme Court of India. She is also strategizing on leading the discussion on climate change into fruitful and effective action on the ground. Ridhima is positive that her efforts as well as the efforts of all the children around the world who are fighting for effective measures to tackle adverse impacts of climate change will definitely bring about a change in the way governments are dealing with the issue. 
Acronyms and abbreviations

EIA Environment Impact Assessment

GHG Greenhouse gas

IPCC Intergovernmental Panel on Climate Change

NAPCC National Action Plan on Climate Change

NGT National Green Tribunal

UNFCCC UN Framework Convention on Climate Change 